\title{
Development and Optimization of a Fluorescent Differential Display PCR System for Analyzing the Stress Response in Lactobacillus sakei Strains
}

\author{
Maria Grazia Bonomo *, Maria Anna Sico, Simona Grieco and Giovanni Salzano \\ Dipartimento di Biologia, Difesa e Biotecnologie Agro-Forestali, Università degli Studi della \\ Basilicata, Viale dell'Ateneo Lucano, 10, 85100 Potenza, Italy; \\ E-Mails: mariaanna.sico@unibas.it (M.A.S.); giovanni.salzano@unibas.it (G.S.); \\ simona@viavai.com (S.G.).
}

* Author to whom correspondence should be addressed: E-Mail: mariagrazia.bonomo@unibas.it. Received: 17 September 2009 / Accepted: 25 November 2009 / Published: 30 November 2009

\begin{abstract}
Lactobacillus sakei is widely used as starter in the production process of Italian fermented sausages and its growth and survival are affected by various factors. We studied the differential expression of genome in response to different stresses by the fluorescent differential display (FDD) technique. This study resulted in the development and optimization of an innovative technique, with a high level of reproducibility and quality, which allows the identification of gene expression changes associated with different microbial behaviours under different growth conditions.
\end{abstract}

Keywords: Fluorescent Differential Display PCR; Lactobacillus sakei; stress response

\section{Introduction}

Lactic acid bacteria are widely used in meat fermentation and an efficient control of these microbiological processes requires increased knowledge of bacterial behaviour under stress conditions. Lactobacillus (Lb.) sakei is recognized as one of the most important components of starter cultures used for production of Italian fermented sausages and its growth and survival are affected by various factors such as temperature, $\mathrm{pH}$ and salt concentration [1]. Recently, the genome of the sausage isolate L. sakei $23 \mathrm{~K}$ was studied, analyzed [2] and then its sequence was published [3] and further investigated [4], providing fundamental information on the genetic makeup of this organism. 
Several techniques, such as differential display (DD-PCR) [5] and RNA arbitrarily primed polymerase chain reaction (RAP-PCR) [6], have been developed and have now become routine to interpret gene expression patterns in different biological systems. The DD-PCR method was originally developed for use in the study of eukaryotic gene expression, and consists of cDNA production from mRNA that has been reversely transcribed with different primers anchored to the polyadenylated tail, followed by amplification of cDNAs with arbitrary primers, with incorporation of a radioactive label and electrophoresis in polyacrylamide sequencing gels [5-7]. RAP-PCR utilizes an arbitrary primer at a low annealing temperature for cDNA synthesis reactions, so it was used for amplification of RNAs that are not polyadenylated, such as bacterial RNA [6]. This technology has been applied to only a few prokaryotic systems [8-13].

Fluorescent differential display (FDD) represents the next logical progression which use labeled primers or direct incorporation of labeled dNTPs and have been widely used and have replaced radioactive detection in many procedures $[14,15]$. FDD, optimized using fluorochrome labeled anchor primers and higher dNTP concentrations in PCR, was shown to be essentially identical in both sensitivity and reproducibility to that of conventional DD. Improvements such as elimination of radioactivity, digital data acquisition and increased assay speed were goals that were successfully achieved with the establishment of the FDD platform, representing a marked improvement over conventional DD [16]. The FDD technique was used in some studies [17-20] and this methodology allows the examination of changes in gene expression in response to different situations without the need of any prior knowledge of genomic information or selecting candidate genes that may be involved in the stress mechanisms. In this way, novel genes may be identified, as already occurred in several previous studies [17,18,21,22].

We have tried to optimize and standardize an assay system based on the FDD method to apply it to prokaryotic systems in order to identify gene expression changes associated with differential microbial behaviours under different growth conditions with a rapid, simple test and with a high level of reproducibility and quality. Thus, the aim of this study was to develop and optimize the FDD method for analyzing the different expression fingerprints of $L b$. sakei in order to verify the applicability of the selected potential starters and to obtain a better stress response definition in this species. We have developed an innovative FDD-PCR protocol that allows us to identify differently expressed transcripts and to compare the difference of cDNA fingerprints when different treatments and time periods are involved.

\section{Results and Discussion}

Fluorescent differential display profiles were produced using an assay system based on the FDD method, by employing a single fluorescently labeled random primer for detecting and isolating differentially expressed fragments under different stress situations.

It has been necessary to first perform a series of laboratory tests in order to optimize the work protocol and to standardize the method for our research, since the differential display amplification of RNA from bacteria cultured independently under identical conditions produced widely different product patterns. Some modifications, detailed in the following section, were made to the standard protocol to obtain a reproducible and standardized method to identify differences in genome 
expression. First of all, three concentrations of RNA were evaluated to overcome the problem of concentration-dependent amplification. Although broadly similar from lane to lane, there were RNAdependent differences in the number of PCR products detected. A plateau in the number of well resolved and easily detected products was observed at about $2 \mu \mathrm{g}$ of RNA, so this RNA concentration was selected for use in the cDNA synthesis reaction (data not shown). Moreover, as FDD-PCR depends on the random priming of a universal random primer at low annealing temperature, the effect of different annealing temperatures in the second-strand synthesis reaction was investigated. The second-strand annealing temperature was increased from 30 to $42{ }^{\circ} \mathrm{C}$ and, with interest in maximizing both the number and the resolution of PCR products, in the end $36^{\circ} \mathrm{C}$ was chosen as the second-strand annealing temperature in subsequent reactions. Equilibration to a specific annealing temperature prior to the addition of Taq polymerase is essential for eliminating the variability inherent to random priming; thus, each sample was randomly primed essentially to completeness prior to the initiation of polymerization, and polymerization was initiated under identical conditions (data not shown). The reproducibility of the FDD technique described in the present work was assessed performing the PCR reactions for each condition tested in triplicate and comparing the obtained fingerprints by compare lane analysis. Figure 1 shows a comparative lane analysis of the three profiles for a representative strain response to one of the stress conditions. It was observed that three independent but identical amplifications of each RNA preparation yielded identical product patterns; the complete peak overlap represents the presence of the same bands in all fingerprints produced, demonstrating the high reproducibility of the method used. We carried out this analysis for each strain with an high reproducibility of the method by generating the same amplification patterns from the same cDNA samples. The analysis of the tracing peaks was performed by Diversity Database ${ }^{\mathrm{TM}}$ software and it gave $100 \%$ similarity among them, validating the experimental procedure.

Figure 1. Compared lane analysis of the three profiles for a representative strain (DBPZ0329) response to a stress condition.

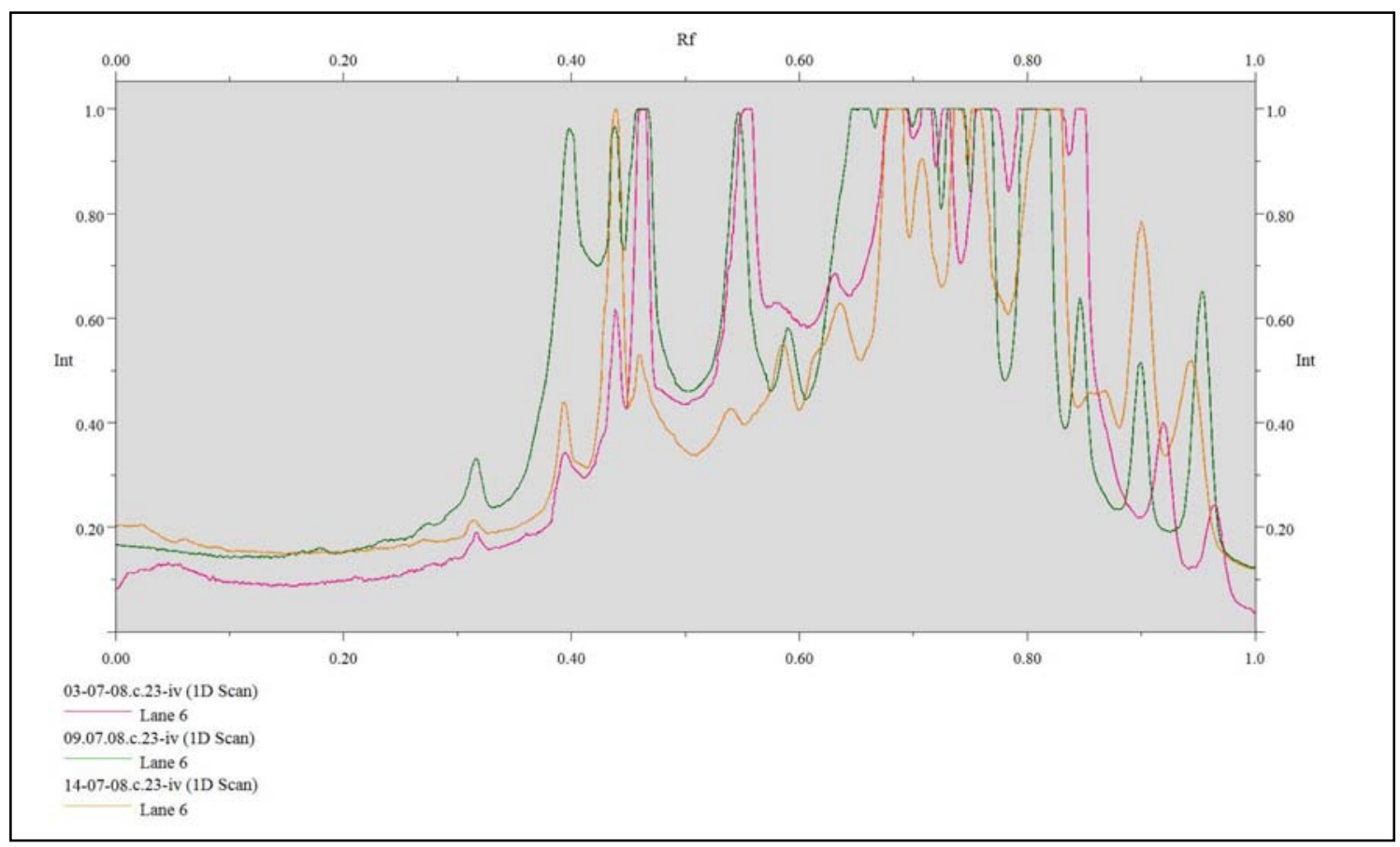


Thus, this work established and optimized a reproducible method that enables the identification of different expression changes of $L b$. sakei in stress conditions, with a reduction in false positives, as already observed in other studies [17-20], and the assessment that the use of 6-FAM-M13 primer resulted in satisfactory band intensity for PCR products, allowing us to also visualize smaller bands as already noted by other authors $[9,11,12,17,18,20]$.

Distinct bands were obtained in response to different stresses, such as low $\mathrm{pH}$ values, elevated temperatures and high osmolarity, and the identification of their sequences is currently under way. The resulting fingerprints showed the presence and the absence of specific products between each stressed sample and the control. \Table 1 shows the fingerprints of each Lb. sakei strain; we can see the band sizes of the specific amplification products present in the control and in the different stressed samples. These products were compared with bands already reported in the literature for stress conditions [4,23-25] and we observed the presence of some bands only in the stressed samples with a molecular weight that can be referred to specific genes under stress situations.

Table 1. Fingerprints of $L b$. sakei strains under stress conditions. The values indicate a molecular weight (expressed in base pairs) of the bands find in the control and in each stressed sample.

\begin{tabular}{|c|c|c|c|c|c|c|}
\hline \multicolumn{7}{|c|}{ DBPZ0098 } \\
\hline Control & $50^{\circ} \mathrm{C}$ & $55^{\circ} \mathrm{C}$ & $60^{\circ} \mathrm{C}$ & pH 2.5 & pH 3 & NaCl 9\% \\
\hline \multirow[t]{3}{*}{1673.44} & \multirow{3}{*}{1328.16} & 1673.44 & \multirow[b]{2}{*}{1328.16} & \multirow[b]{2}{*}{1328.16} & \multirow[t]{3}{*}{1673.44} & \multirow[t]{4}{*}{1673.44} \\
\hline & & 1018.72 & & & & \\
\hline & & 931.93 & 931.93 & 931.93 & & \\
\hline 882.75 & 882.75 & 882.75 & 882.75 & 882.75 & \multirow[t]{2}{*}{882.75} & \\
\hline 864.42 & 864.42 & & & & & 864.42 \\
\hline 834.89 & 834.89 & 834.89 & 834.89 & 834.89 & & 834.89 \\
\hline 784.89 & 784.89 & 784.89 & 784.89 & 784.89 & \multirow[t]{2}{*}{784.89} & \\
\hline 749.74 & & 749.74 & 749.74 & 749.74 & & 749.74 \\
\hline 693.97 & 693.97 & 693.97 & 693.97 & 693.97 & 693.97 & 693.97 \\
\hline \multirow[t]{2}{*}{663.45} & & 663.45 & 663.45 & 663.45 & \multirow[t]{2}{*}{663.45} & \\
\hline & 632.92 & 632.92 & & & & \multirow{3}{*}{587.53} \\
\hline \multirow[t]{2}{*}{587.53} & 587.53 & 587.53 & \multirow[t]{2}{*}{587.53} & \multirow[t]{2}{*}{587.53} & & \\
\hline & 550.05 & & & & & \\
\hline 530.28 & 530.28 & 530.28 & 530.28 & 530.28 & 530.28 & 530.28 \\
\hline \multirow[t]{2}{*}{504.74} & 504.74 & 504.74 & \multirow[t]{2}{*}{504.74} & \multirow[t]{2}{*}{504.74} & \multirow[t]{2}{*}{504.74} & \multirow[t]{2}{*}{504.74} \\
\hline & 486.83 & 486.83 & & & & \\
\hline 469.53 & 469.53 & 469.53 & 469.53 & 469.53 & 469.53 & 469.53 \\
\hline 452.86 & 452.86 & 452.86 & 452.86 & 452.86 & 452.86 & 452.86 \\
\hline 417.27 & 417.27 & 417.27 & 417.27 & 417.27 & 417.27 & 417.27 \\
\hline \multicolumn{7}{|c|}{ DBPZ0338 } \\
\hline Control & $50^{\circ} \mathrm{C}$ & $55^{\circ} \mathrm{C}$ & $60^{\circ} \mathrm{C}$ & pH 2.5 & pH 3 & NaCl 9\% \\
\hline \multirow[t]{2}{*}{2560.91} & 2560.91 & 2560.91 & \multirow[t]{2}{*}{2560.91} & \multirow[t]{5}{*}{2560.91} & \multirow{5}{*}{980.06} & \multirow[t]{3}{*}{2560.91} \\
\hline & & 1750.63 & & & & \\
\hline & & 1450.49 & & & & \\
\hline \multirow[t]{3}{*}{980.06} & & & \multirow{4}{*}{$\begin{array}{l}980.06 \\
970.73\end{array}$} & & & \\
\hline & 970.73 & & & & & \\
\hline & & & & & & 851.94 \\
\hline 773.31 & 773.31 & 773.31 & & & 773.31 & \\
\hline
\end{tabular}


Table 1. Cont.

\begin{tabular}{|c|c|c|c|c|c|c|}
\hline & 738.01 & & & & & \\
\hline 704.32 & 704.32 & & 704.32 & 704.32 & 704.32 & 704.32 \\
\hline 674.71 & 674.71 & & 674.71 & & 674.71 & 674.71 \\
\hline 600.51 & 600.51 & 600.51 & 600.51 & 600.51 & 600.51 & 600.51 \\
\hline 571.08 & 571.08 & 571.08 & 571.08 & 571.08 & 571.08 & 571.08 \\
\hline 532.01 & 532.01 & 532.01 & 532.01 & 532.01 & 532.01 & 532.01 \\
\hline 513.04 & 513.04 & 513.04 & 513.04 & 513.04 & 513.04 & 513.04 \\
\hline 336.57 & 336.57 & 336.57 & 336.57 & 336.57 & 336.57 & 336.57 \\
\hline & & & DBPZ0416 & & & \\
\hline Control & $50^{\circ} \mathrm{C}$ & $5^{\circ} \mathrm{C}$ & $60^{\circ} \mathrm{C}$ & pH 2.5 & pH 3 & $\mathrm{NaCl}$ 9\% \\
\hline & 6032.41 & & & & & \\
\hline 5370.14 & & 5370.14 & 5370.14 & & $\begin{array}{l}5370.14 \\
\mathbf{3 6 5 3 . 5 6}\end{array}$ & 5370.14 \\
\hline 3292.21 & & 3292.21 & 3292.21 & & 3292.21 & 3292.21 \\
\hline 2721.33 & 2721.33 & & 2721.33 & 2721.33 & & 2721.33 \\
\hline 2473.01 & 2473.01 & 2473.01 & 2473.01 & & 2473.01 & 2473.01 \\
\hline 2383.11 & & & 2383.11 & & 2383.11 & 2383.11 \\
\hline & 2276.34 & 2276.34 & & 2276.34 & & \\
\hline 2184.14 & & & 2184.14 & 2184.14 & 2184.14 & 2184.14 \\
\hline 2022.33 & 2022.33 & 2022.33 & 2022.33 & & 2022.33 & 2022.33 \\
\hline 1875.22 & 1875.22 & 1875.22 & 1875.22 & 1875.22 & 1875.22 & 1875.22 \\
\hline 1771.13 & 1771.13 & 1771.13 & 1771.13 & 1771.13 & 1771.13 & 1771.13 \\
\hline 1720.02 & 1720.02 & 1720.02 & 1720.02 & 1720.02 & 1720.02 & 1720.02 \\
\hline 1642.11 & 1642.11 & 1642.11 & 1642.11 & 1642.11 & 1642.11 & 1642.11 \\
\hline 1544.23 & 1544.23 & & & 1544.23 & 1544.23 & 1544.23 \\
\hline 1454.23 & 1454.23 & 1454.23 & 1454.23 & 1454.23 & 1454.23 & 1454.23 \\
\hline 1323.41 & 1323.41 & 1323.41 & 1323.41 & & 1323.41 & 1323.41 \\
\hline 1151.11 & & 1151.11 & & & & 1151.11 \\
\hline & 1074.03 & & & & & \\
\hline 880.12 & & 880.12 & 880.12 & 880.12 & 880.12 & 880.12 \\
\hline 863.45 & 863.45 & 863.45 & 863.45 & & 863.45 & 863.45 \\
\hline 740.53 & & & & & & \\
\hline & 643.75 & 643.75 & 643.75 & 643.75 & & \\
\hline 600.21 & 600.21 & 600.21 & 600.21 & 600.21 & 600.21 & 600.21 \\
\hline & 576.43 & & & & & \\
\hline 512.01 & 512.01 & 512.01 & 512.01 & 512.01 & 512.01 & 512.01 \\
\hline 486.52 & 486.52 & 486.52 & 486.52 & 486.52 & 486.52 & 486.52 \\
\hline 478.59 & & 478.59 & 478.59 & & & 478.59 \\
\hline 441.67 & & & 441.67 & 441.67 & & \\
\hline 412.34 & 412.34 & & 412.34 & 412.34 & & \\
\hline & & & & 387.54 & & \\
\hline 365.55 & 365.55 & 365.55 & 365.55 & 365.55 & & 365.55 \\
\hline & & 354.22 & 354.22 & & 354.22 & \\
\hline & 304.53 & & & 304.53 & & \\
\hline & 291.23 & & & 291.23 & & 291.23 \\
\hline
\end{tabular}


Table 1. Cont.

\begin{tabular}{|c|c|c|c|c|c|c|}
\hline \multicolumn{7}{|c|}{ DBPZ0062 } \\
\hline Control & $50^{\circ} \mathrm{C}$ & $55^{\circ} \mathrm{C}$ & $60^{\circ} \mathrm{C}$ & pH 2.5 & pH 3 & $\mathrm{NaCl} 9 \%$ \\
\hline & & & & & & \\
\hline & & 5461.79 & & & & \\
\hline \multirow[t]{3}{*}{3862.88} & 3862.88 & & 3862.88 & & & 3862.88 \\
\hline & & 3333.04 & & & & \\
\hline & & & & 2441.51 & & 2441.51 \\
\hline 1685.79 & & & & & & 1685.79 \\
\hline 1503.95 & 1503.95 & 1503.95 & & 1503.95 & & \\
\hline \multirow[t]{2}{*}{1166.63} & 1166.63 & 1166.63 & 1166.63 & 1166.63 & & 1166.63 \\
\hline & & 1039.42 & & 1039.42 & & \\
\hline \multicolumn{7}{|l|}{964.55} \\
\hline 901.32 & 901.32 & 901.32 & 901.32 & 901.32 & 901.32 & 901.32 \\
\hline 870.74 & 870.74 & & & & & 870.74 \\
\hline 840.71 & & & & & 840.71 & \\
\hline 796.05 & 796.05 & 796.05 & 796.05 & 796.05 & & \\
\hline \multicolumn{7}{|l|}{705.81} \\
\hline 687.53 & 687.53 & 687.53 & 687.53 & 687.53 & 687.53 & 687.53 \\
\hline \multirow[t]{2}{*}{649.93} & 649.93 & 649.93 & 649.93 & & 649.93 & 649.93 \\
\hline & & 636.22 & & 636.22 & & \\
\hline \multicolumn{7}{|l|}{615.23} \\
\hline 607.29 & 607.29 & 607.29 & 607.29 & 607.29 & 607.29 & 607.29 \\
\hline 584.36 & 584.36 & 584.36 & 584.36 & 584.36 & 584.36 & 584.36 \\
\hline 543.07 & 543.07 & 543.07 & 543.07 & 543.07 & 543.07 & 543.07 \\
\hline \multirow[t]{4}{*}{511.96} & 511.96 & 511.96 & 511.96 & 511.96 & 511.96 & \\
\hline & & & 497.97 & & 497.97 & \\
\hline & 472.33 & & & 472.33 & 472.33 & 472.33 \\
\hline & & & & & 451.2 & \\
\hline 433.57 & 433.57 & 433.57 & 433.57 & 433.57 & 433.57 & 433.57 \\
\hline \multicolumn{7}{|c|}{ DBPZ0329 } \\
\hline \multirow[t]{5}{*}{ Control } & $50^{\circ} \mathrm{C}$ & $55^{\circ} \mathrm{C}$ & $60^{\circ} \mathrm{C}$ & pH 2.5 & pH 3 & NaCl 9\% \\
\hline & & & 1722.17 & 1722.17 & & \\
\hline & & & & 1468.41 & & \\
\hline & & & 1422.94 & & & \\
\hline & & & 1308.32 & & & \\
\hline \multirow[t]{3}{*}{1022.48} & 1022.48 & 1022.48 & 1022.48 & 1022.48 & 1022.48 & 1022.48 \\
\hline & & & 965.71 & & & 965.71 \\
\hline & & 943.36 & 943.36 & 943.36 & 943.36 & 943.36 \\
\hline \multirow[t]{2}{*}{873.34} & & 873.34 & 873.34 & 873.34 & 873.34 & 873.34 \\
\hline & & & 840.95 & & & \\
\hline \multirow[t]{2}{*}{805.84} & & & & & 805.84 & \\
\hline & & & & 779.32 & & 779.32 \\
\hline 759.71 & & 759.71 & 759.71 & & & \\
\hline \multirow[t]{3}{*}{746.03} & & 746.03 & & & 746.03 & \\
\hline & & & 708.68 & 708.68 & 708.68 & \\
\hline & & 702.39 & & 702.39 & 702.39 & 702.39 \\
\hline \multirow[t]{3}{*}{697.99} & & & 697.99 & 697.99 & 697.99 & 697.99 \\
\hline & & 673.84 & & & & \\
\hline & & 663.54 & 663.54 & 663.54 & 663.54 & 663.54 \\
\hline 659.26 & & 659.26 & 659.26 & & 659.26 & 659.26 \\
\hline
\end{tabular}


Table 1. Cont.

\begin{tabular}{|l|l|l|l|l|l|l|}
\hline 624.48 & 624.48 & 624.48 & 624.48 & 624.48 & 624.48 & 624.48 \\
\hline & & $\mathbf{5 9 7 . 4 2}$ & 597.42 & & & 597.42 \\
\hline & & $\mathbf{5 7 0 . 5 8}$ & & & 570.58 & 570.58 \\
\hline 548.10 & 548.10 & 548.10 & 548.10 & 548.10 & 548.10 & 548.10 \\
\hline & & & & $\mathbf{5 4 6 . 1 8}$ & & 546.18 \\
\hline & & 527.78 & 527.78 & 527.78 & 527.78 & \\
\hline 522.14 & & 522.14 & 522.14 & 522.14 & & 522.14 \\
\hline 501.79 & 501.79 & 501.79 & 501.79 & 501.79 & 501.79 & 501.79 \\
\hline 494.21 & 494.21 & & & 494.21 & & \\
\hline 479.58 & 479.58 & 479.58 & 479.58 & 479.58 & 479.58 & 479.58 \\
\hline & & $\mathbf{4 7 0 . 7 9}$ & & & & \\
\hline 459.58 & 459.58 & 459.58 & 459.58 & 459.58 & 459.58 & 459.58 \\
\hline & & $\mathbf{4 4 8 . 3 7}$ & & & & \\
\hline 414.21 & 414.21 & & 414.21 & 414.21 & 414.21 & 414.21 \\
\hline 389.06 & 389.06 & 389.06 & 389.06 & 389.06 & 389.06 & 389.06 \\
\hline
\end{tabular}

As a random analysis on mRNA transcript was performed, it might be possible that some fragments obtained are part of genes known or not yet known, so we decided to compare accurately each lane of the stressed sample with that of the control (Figure 2) in order to analyze and choose the more interesting bands.

Figure 2. Analysis of the fingerprints obtained by comparing each lane of the stressed sample with that of the control. (a) Stressed sample at $50{ }^{\circ} \mathrm{C}$ and the control. (b) Stressed sample at $55{ }^{\circ} \mathrm{C}$ and the control. (c) Stressed sample at $60{ }^{\circ} \mathrm{C}$ and the control. (d) Stressed sample at pH 2.5 and the control. (e) Stressed sample at pH 3 and the control. (f) Stressed sample at $9 \% \mathrm{NaCl}$ and the control.

(a)

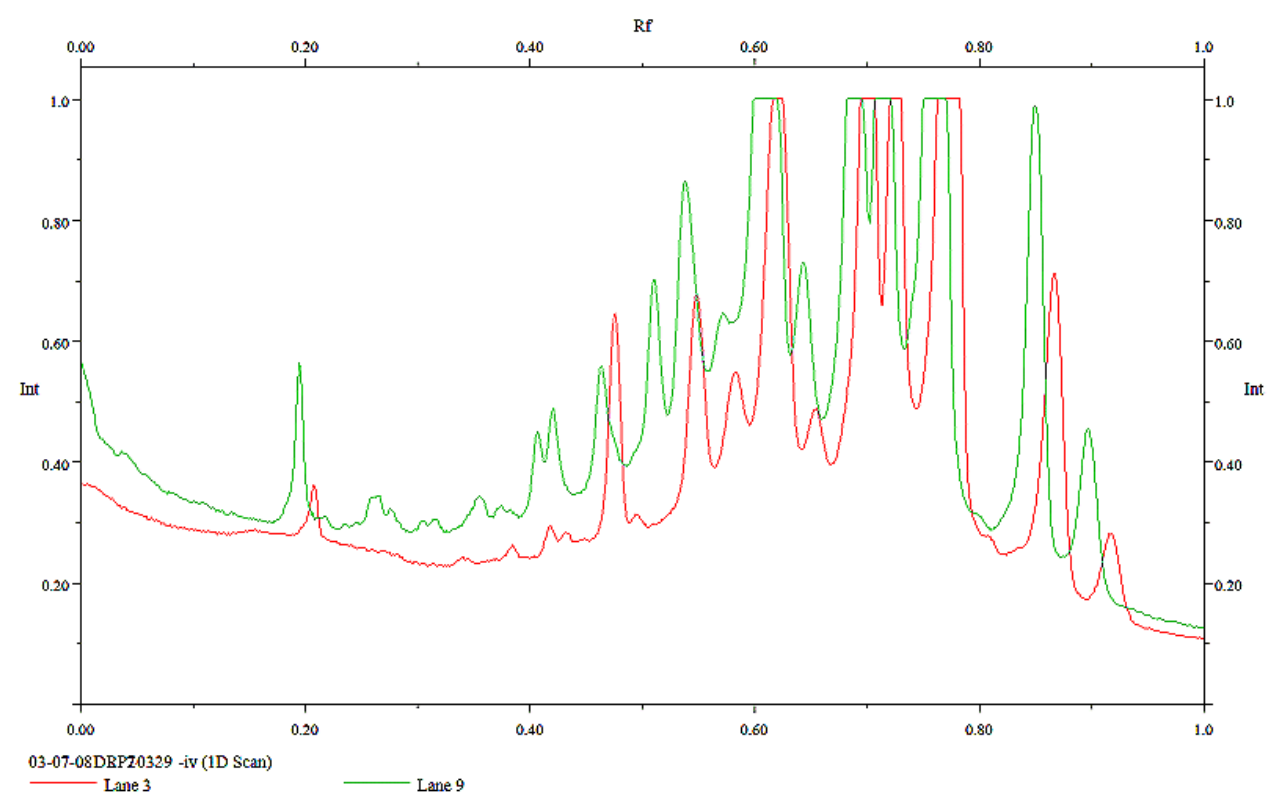


Figure 2. Cont.

(b)

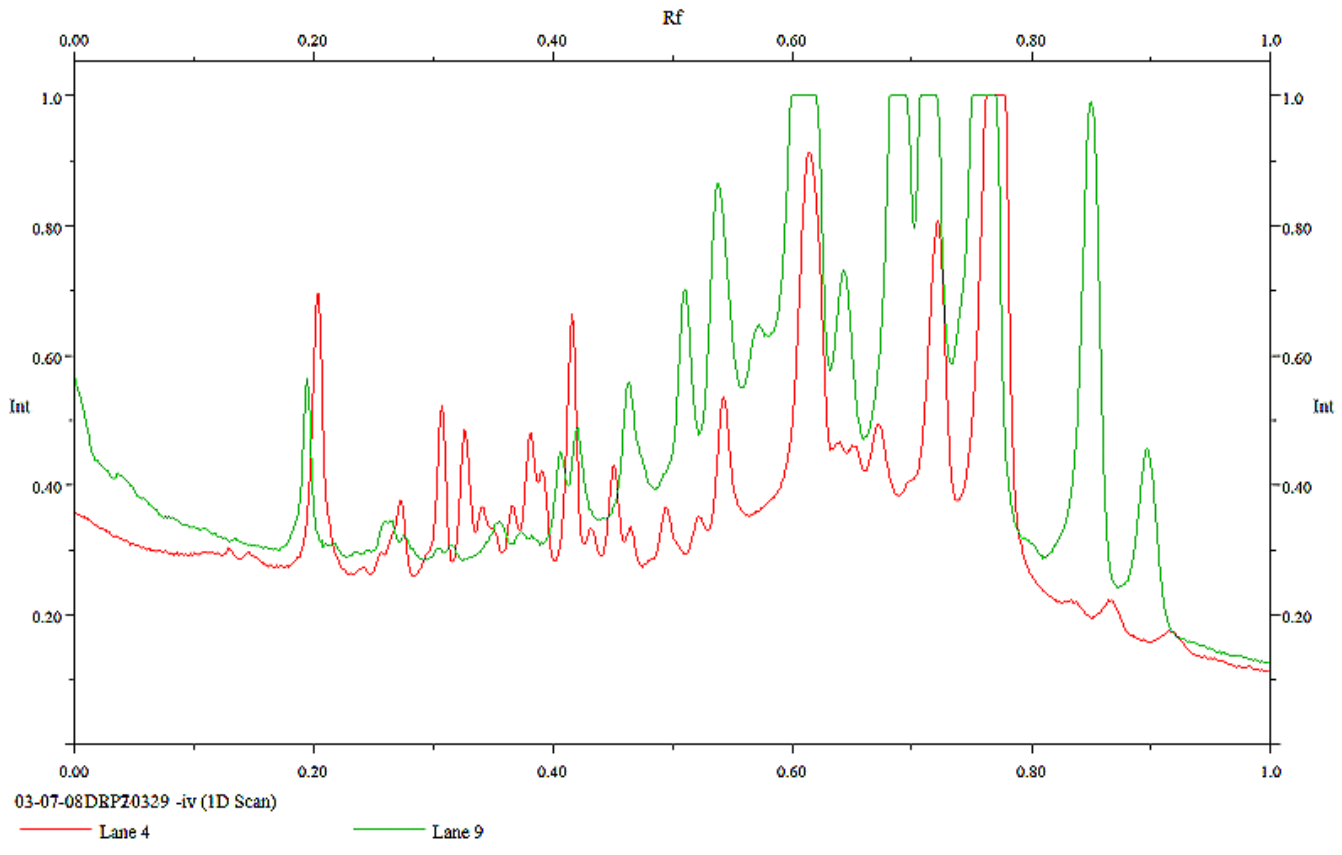

(c)

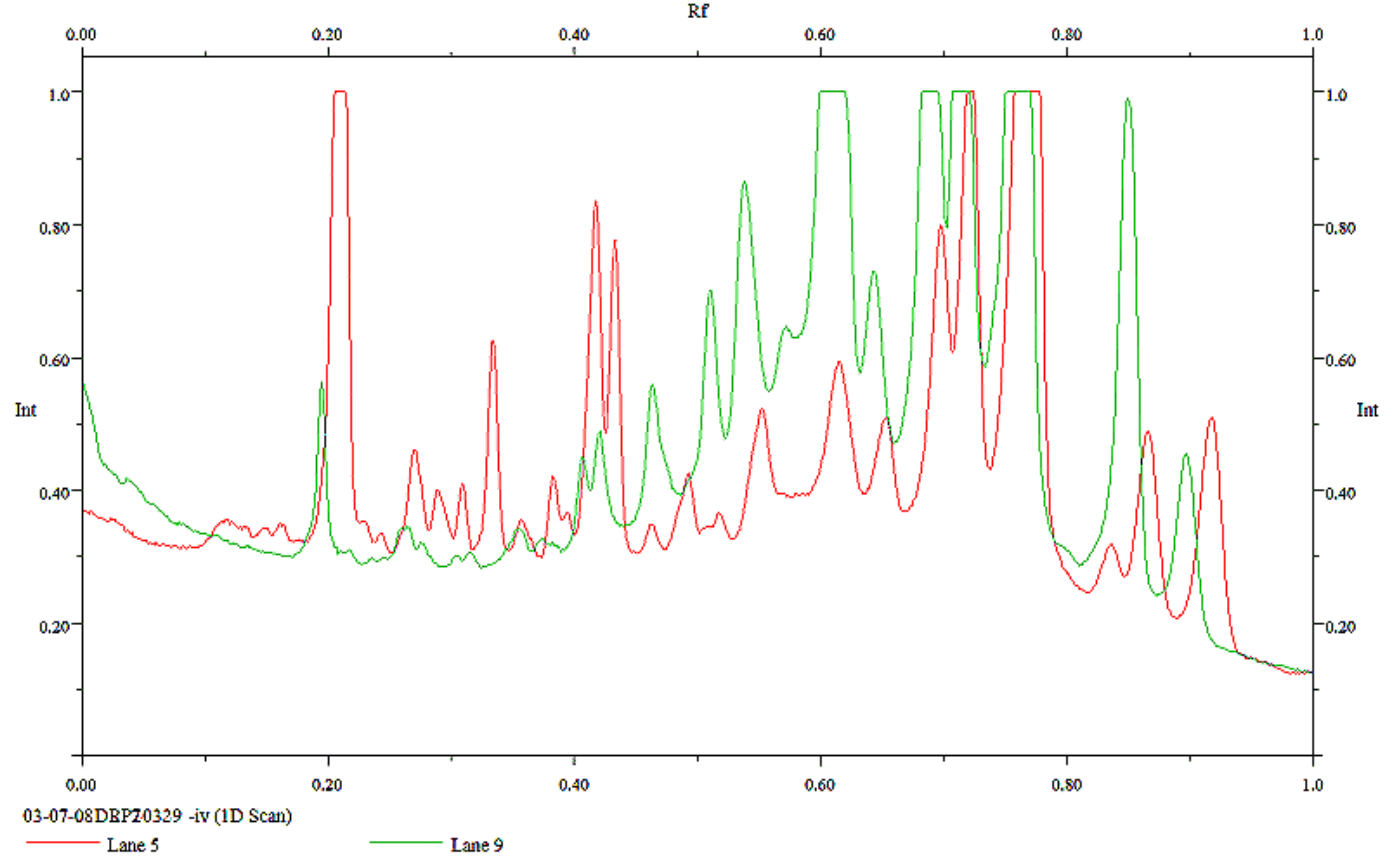


Figure 2. Cont.

(d)

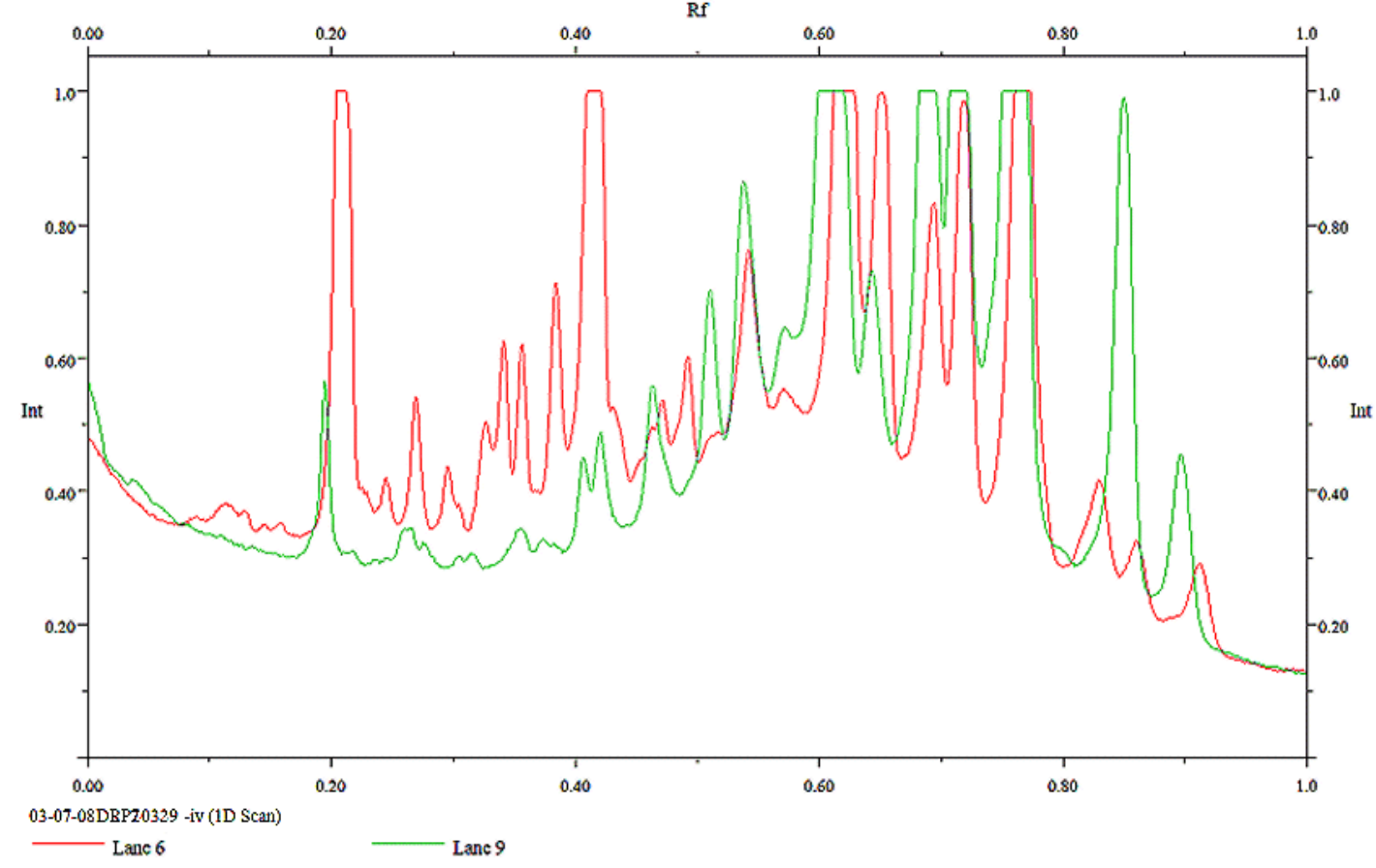

(e)

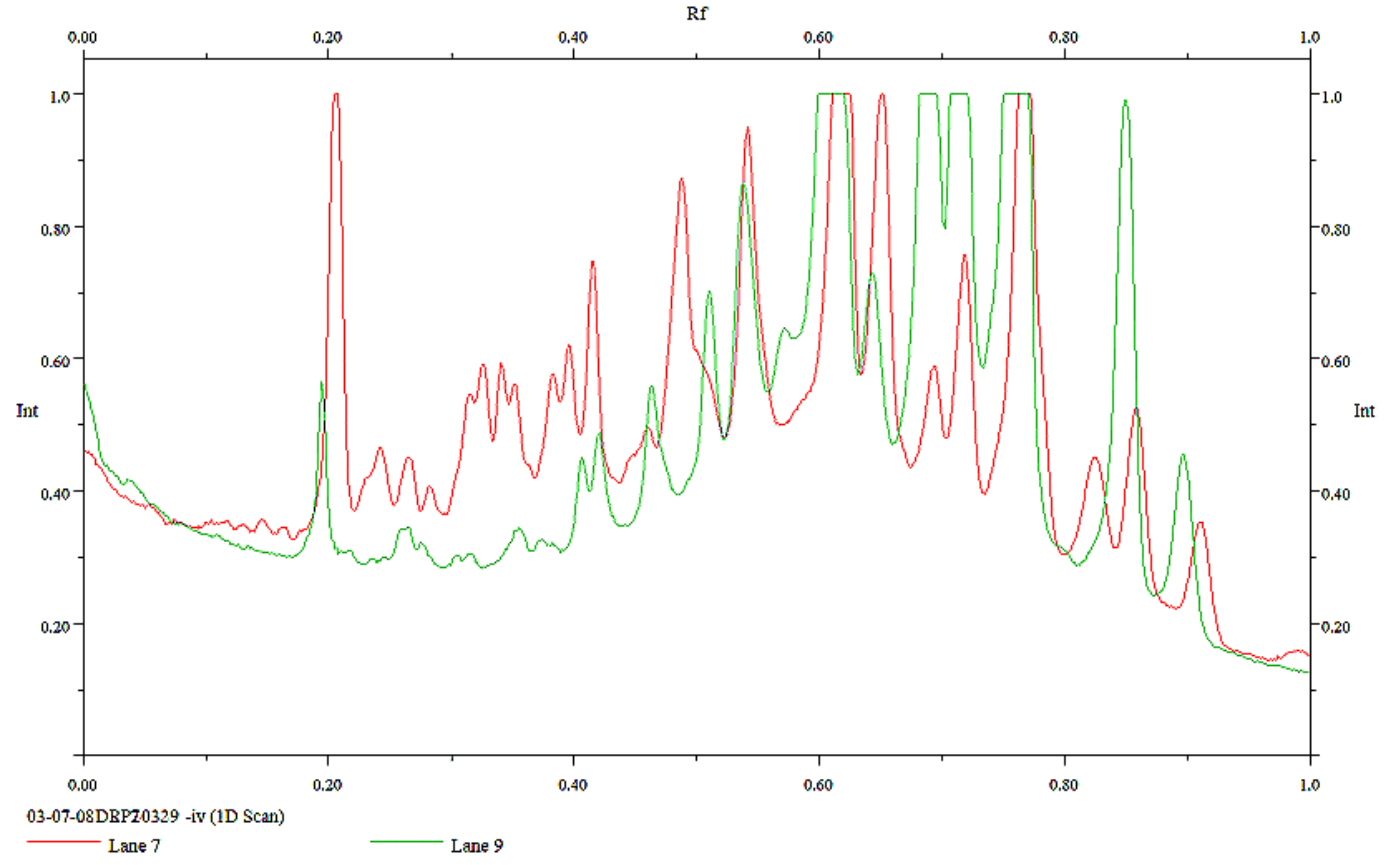


Figure 2. Cont.

(f)

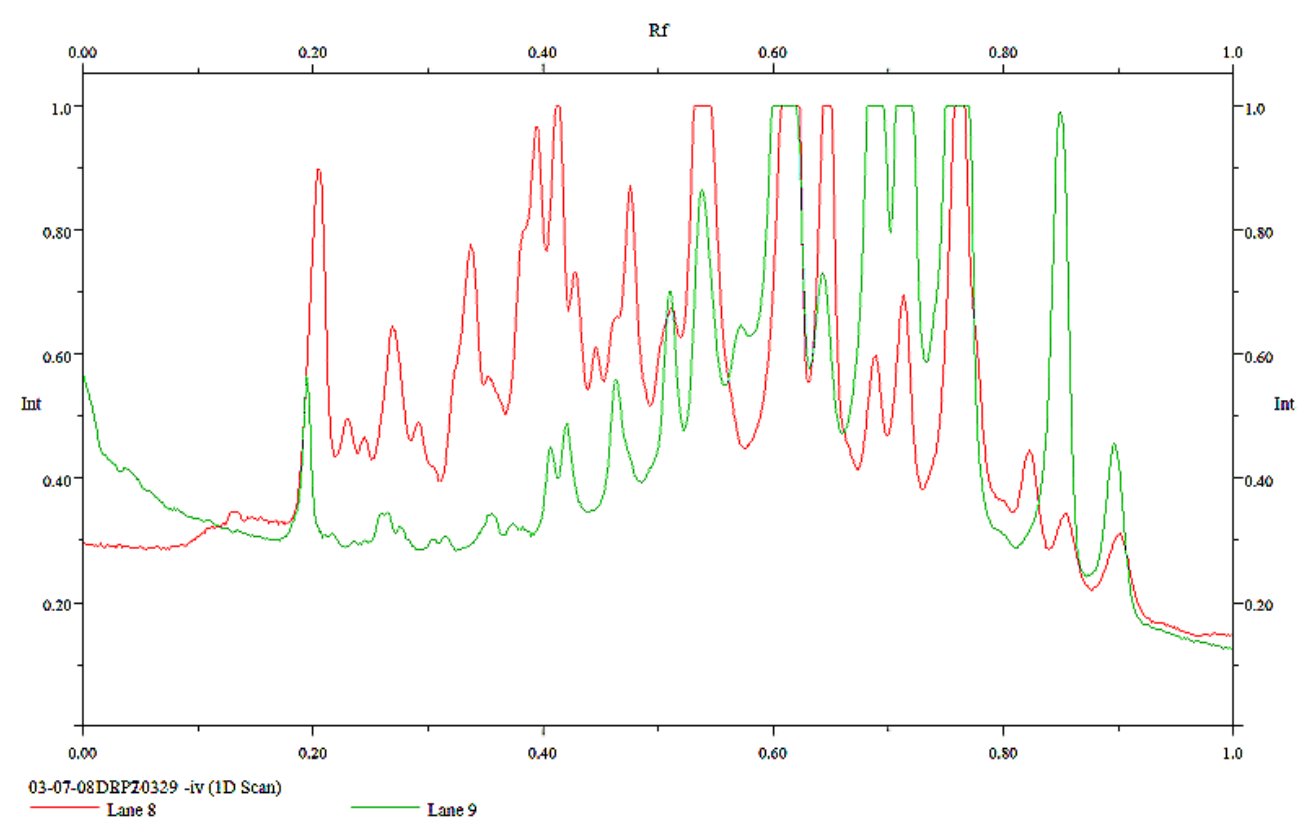

As shown in this Figure, the analysis demonstrated the expression of specific products by comparison of tracings related to the different samples lanes in particular stress conditions. The compare lane analysis proved the presence of some bands and the absence of others, so it evidenced that, in order to survive and adjust to the stresses encountered, Lb. sakei strains respond to stimuli through the differential expression of transcripts. Bands of interest (labelled in bold in Table 1) were selected, recovered and re-amplified by standard PCR with the same universal primer used in FDD-PCR. After re-amplification, the products were gel purified and sent for sequencing and their identification is currently underway. The results of this analysis confirmed the effectiveness of the system at identifying differentially expressed transcripts on FDD fingerprints correlated with microbial tolerance to stress situations. Sequence and expression studies are currently under way and then an additional search is required to gather information essential to determine the functional role of these genes.

\section{Experimental Section}

\subsection{Bacterial Strains and Culture Conditions}

Five strains of Lb. sakei (DBPZ0062, DBPZ0098, DBPZ0338, DBPZ0329 and DBPZ0416) from the culture collection of the Dipartimento di Biologia, Difesa e Biotecnologie Agro-Forestali, Università degli Studi della Basilicata, Potenza, Italy, used in this study were isolated from traditional fermented sausages of the Basilicata region and chosen as potential autochthonous starters in a previous study [26]. All strains were maintained as freeze-dried stocks in reconstituted $(11 \% \mathrm{w} / \mathrm{v})$ 
skim milk, containing 0.1\% w/v ascorbic acid (Riedel-de Haën, Sigma-Aldrich, Milan, Italy) and routinely cultivated in MRS broth at $30^{\circ} \mathrm{C}$ for $16 \mathrm{~h}$, before the evaluation of stress response.

\subsection{Stress Treatments}

Late-exponential phase cells grown overnight in MRS broth, $\mathrm{pH} 6.2$, were harvested by centrifugation $(12,000 \mathrm{rpm}, 5 \mathrm{~min})$ and washed twice in sterile saline solution $(0.85 \% \mathrm{w} / \mathrm{v} \mathrm{NaCl})$. The cells were re-suspended in $2 \mathrm{~mL}$ of different media to a final $\mathrm{OD}_{600}=1.0$ to achieve the following stress conditions: (a) MRS broth, $\mathrm{pH} 2.5$ and 3.0 (adjusted with $\mathrm{HCl}$, acid stress); (b) MRS broth with $9 \% \mathrm{w} / \mathrm{v} \mathrm{NaCl}$ (osmotic stress); (c) MRS broth, $\mathrm{pH} \mathrm{6.2,} \mathrm{at} \mathrm{different} \mathrm{temperatures} \mathrm{(heat} \mathrm{stress).} \mathrm{Cell}$ suspensions were incubated for $30 \mathrm{~min}$ at $30{ }^{\circ} \mathrm{C}$ for acid and osmotic stresses and at 50, 55 and $60{ }^{\circ} \mathrm{C}$ for heat stress. Bacterial cells incubated at $30^{\circ} \mathrm{C}$ for $30 \mathrm{~min}$ in $2 \mathrm{~mL}$ of MRS broth, $\mathrm{pH} 6.2$, were used as controls.

\subsection{Fluorescent Differential Display (FDD)}

RNA was extracted from $2 \mathrm{~mL}$ of $L b$. sakei culture using RNA isolation kit supplied by Gentra System, Inc. (Minneapolis, MN, USA) according to the manufacturer's instructions. Purified RNAs were suspended in $200 \mu \mathrm{L}$ of DEPC $0.1 \%$ diethylpyrocarbonate-treated water and stored at $-20{ }^{\circ} \mathrm{C}$. RNAs concentrations were calculated by measuring absorbance at $260 \mathrm{~nm}$ using the NanoDrop ${ }^{\circledR}$ ND1000 spectrophotometer (Nanodrop Technologies Inc.). Prior to reverse transcription (RT), RNA (2 $\mu \mathrm{g}$ of total RNA) was treated with $2 \mathrm{U} / \mu \mathrm{L}$ of RNase-free DNase (Ambion, Applied Biosystems, Austin, TX, USA), as described by the manufacturer, to achieve complete DNA removal. Then, the cDNA was synthesized using the ProSTAR ${ }^{\mathrm{TM}}$ First-Strand RT-PCR kit (stratagene, La Jolla, CA, USA) as recommended. RT reactions were performed in a final volume of $150 \mu \mathrm{L}$ that contained master mix, random primers and $10 \mu \mathrm{L}$ of RNA by subsequent incubation at $80{ }^{\circ} \mathrm{C}$ for $3 \mathrm{~min}$, at $42{ }^{\circ} \mathrm{C}$ for $2 \mathrm{~h}$ and at $16{ }^{\circ} \mathrm{C}$ for $2 \mathrm{~h}$. After diluition, $2 \mu \mathrm{L}$ of cDNA were used for PCR analyses.

The FDD technique was carried out by using a single fluorescently labeled universal primer, the random 6-carboxyfluorescein labeled 5'-anchored M13 primer (5'-6-carboxyfluorescein (FAM)GAGGGTGGCGGTTCT-3'). The PCR mixture (25 $\mu \mathrm{L})$ consisted of $2 \mu \mathrm{L}$ of diluted cDNA, $2.5 \mu$ of 1X PCR buffer (EuroClone, Pero, Milano, Italy), $3 \mathrm{mM}$ of $\mathrm{MgCl}_{2}$ (EuroClone), $0.4 \mathrm{mM}$ of each dNTP (EuroClone), $0.6 \mu \mathrm{M}$ of the primer (Invitrogen Ltd, Paisley,UK), $2.5 \mathrm{U}$ of Taq polymerase (EuroClone). PCR amplification was carried out in a Genius Techne Progene thermal cycler (Cambridge, UK) using the following program: initial denaturation at $94{ }^{\circ} \mathrm{C}$ for $1 \mathrm{~min}$; 40 cycles of $94{ }^{\circ} \mathrm{C}$ for $1 \mathrm{~min}$, annealing at $36{ }^{\circ} \mathrm{C}$ for $1 \mathrm{~min}$ and extension at $72{ }^{\circ} \mathrm{C}$ for $2 \mathrm{~min}$; followed by a final extension at $72{ }^{\circ} \mathrm{C}$ for $7 \mathrm{~min}$. The PCR products were separated by electrophoresis on $2 \%(\mathrm{w} / \mathrm{v})$ agarose gels (EuroClone) in $1 \mathrm{X}$ TBE at $100 \mathrm{~V}$ for $4 \mathrm{~h}$. Gels were stained in $1 \mathrm{X}$ TBE buffer containing $0.5 \mu \mathrm{g} / \mathrm{mL}$ ethidium bromide (Serva Electrophoresis $\mathrm{GmbH}$, Heidelberg, Germany) for $30 \mathrm{~min}$. A $1 \mathrm{~kb}$ DNA ladder (EuroClone) was used as molecular weight and normalization gel standard.

The banding patterns were visualized by UV transillumination and captured with GelDoc 2,000 Apparatus (BioRad). Gel images were digitized in Diversity Database ${ }^{\mathrm{TM}}$ software (Bio-Rad Laboratories Ltd., Watford, Herts, UK) and processed for analysis and selection of the fragments. 
PCR reactions were done in triplicate and the comparison of obtained fingerprints was carried out by using the compare lane analysis feature of the Diversity Database ${ }^{\mathrm{TM}}$ software to demonstrate the reproducibility of the method used and also to analyze and choose more accurately patterns obtained under different conditions tested.

\section{Conclusions}

In this study, the development and the optimization of a technique able to identify gene expression changes, associated with differential microbial behaviours under different growth conditions, was achieved. In this work we tested five $L b$. sakei strains chosen as potential autochthonous starter cultures on the basis of genetic diversity and important technological properties [26] and also more competitive, well adapted to the particular product and to the specific production technology and with high metabolic capacities. The aim was to examine the effective capacity of these strains to withstand and tolerate different stress conditions because the formulation and preservation of starter cultures may impose environmental stresses on the bacterial cells which influence the metabolic activities and decrease the performance of the starters in industry biotechnology. Therefore, the development of rapid and efficient method for studying the effect of stress on bacterial cells is important to verify the applicability of starter cultures subjected to different stresses.

The availability of a reliable method for the differentiation of $L b$. sakei strains is indispensable for a better definition of genotypes developed in different regions of fermented sausages production, with an advance in the evaluation of the genomic differences among strains in order to examine the evolution of this species. Thus, the application of an innovative and promising FDD method, with an high level of reproducibility and quality and the refinements detailed in the present work, allows one to carry out a specific FDD-PCR protocol to serve as a general, highly reproducible and standardized technique for studying and probing the knowledge of the relation between differential genome expression and tolerance to different stresses.

The FDD-PCR isn't a quantitative technique, however, so if and when deemed necessary, some results will be also analyzed by qPCR to achieve further information about the expression level of a particular gene in different conditions, but without invalidating the simplicity of execution and the innovation of the technique applied. The analysis of the transcripts sequences and the investigation of their products and of their role in the stress response and their involvement in physiological changes of bacterial behaviour were the next step of our research.

\section{References and Notes}

1. Leroy, F.; Verluyten, J.; De Vuyst, L. Functional meat starter cultures for improved sausage fermentation. Int. J. Food Microbiol. 2006, 106, 270-285.

2. Marceau, A.; Zagorec, M.; Chaillou, S.; Mera, T.; Champomier-Verges, M.C. Evidence for involvement of at least six proteins in adaptation of Lactobacillus sakei to cold temperatures and addition of NaCl. Appl. Environ. Microbiol. 2004, 70, 7260-7268. 
3. Chaillou, S.; Champomier-Verges, M.C.; Cornet, M.; Crutz-Le Coq, A.M.; Dudez, A.M.; Martin, V.; Beaufils, S.; Darbon-Rongere, E. The complete genome sequence of the meat-borne lactic acid bacterium Lactobacillus sakei 23K. Nat. Biotechnol. 2005, 23, 1527-1533.

4. Hufner, E.; Markieton, T.; Chaillou, S.; Crutz-Le Coq, A.M.; Zagorec, M.; Hertel, C. Identification of Lactobacillus sakei genes induced during meat fermentation and their role in survival and growth. Appl. Environ. Microbiol. 2007, 73, 2522-2531.

5. Liang, P.; Pardee, A.B. Differential display of eukaryotic messenger RNA by means of the polymerase chain reaction. Science 1992, 257, 967-971.

6. Welsh, J.; Chada, K.; Dalal, S.S.; Cheng, R.; Ralph, D.; McClelland, M. Arbitrarily primed PCR fingerprinting of RNA. Nucleic Acids Res. 1992, 20, 4965-4970.

7. McClelland, M.; Mathieu-Daude, F.; Welsh, J. RNA fingerprinting and differential display using arbitrarily primed PCR. Trends Genet. 1995, 11, 242- 246.

8. Wong, K.K.; McClelland, M. Stress-inducible gene of Salmonella typhimurium identified by arbitrarily primed PCR of RNA. Proc. Natl. Acad. Sci. USA 1994, 91, 639-643.

9. Shepard, B.D.; Gilmore, M.S. Identification of aerobically and anaerobically induced genes in Enterococcus faecalis by random arbitrarily primed PCR. Appl. Environ. Microbiol. 1999, 65, $1470-1476$.

10. Du, L.D.; Kolenbrander, P.E. Identification of saliva-regulated genes of Streptococcus gordonii DL1 by differential display using random arbitrarily primed PCR. Infec. Immunity 2000, 68, 4834-4837.

11. Chia, J.S.; Lee, Y.Y.; Huang, P.T.; Chen, J.Y. Identification of stress-responsive genes in Streptococcus mutans by differential display reverse transcription-PCR. Infec. Immunity 2001, 69, 2493-2501.

12. Le Breton, Y.; Muller, C.; Auffray, Y.; Rincé, A. New insights into the Enterococcus faecalis CroRS two-component system obtained using a differential-display random arbitrarily primed PCR approach. Appl. Environ. Microbiol. 2007, 73, 3738-3741.

13. Lechiancole, T.; Blaiotta, G.; Messina, D.; Fusco, V.; Villani, F.; Salzano, G. Evaluation of intraspecific diversities in Oenococcus oeni through analysis of genomic and expressed DNA. Syst. Appl. Microbiol. 2006, 29, 375-381.

14. Reinhardt, B.; Frank, U.; Gellner, K.; Lohmann, J.U. High-resolution, fluorescence based differential display on a DNA sequencer followed by band excision. Biotechniques 1999, 27, 268-271.

15. Cho, Y.J.; Meade, J.D.; Walden, J.C.; Chen, X. Multicolor fluorescent differential display. Biotechnique 2001, 30, 562-572.

16. Liang, P.; Meade, D.; Pardee, A.B. A protocol for differential display of mRNA expression using either fluorescent or radioactive labeling. Nature Protocols 2007, 2, 457-470.

17. Lockyer, A.E.; Noble, L.R.; Rollinson, D.; Jones, C.S. Schistosoma mansoni: resistant specific infection-induced gene expression in Biomphalaria glabrata identified by fluorescent-based differential display. Exp. Parasitol. 2004, 107, 97-104.

18. Xu, J.P.; Chen, K.P.; Yao, Q.; Liu, X.Y. Fluorescent differential display analysis of gene expression for NPV resistance in Bombyx mori L. JEN 2005, 129, 27-31. 
19. Shimizu, M.; Kosaka, N.; Shimada, T.; Nagahata, T.; Iwasaki, H.; Nagai, H.; Shiba, T.; Emi, M. Universal fluorescent labeling (UFL) method for automated microsatellite analysis. DNA Res. 2002, 9, 173-178.

20. Ripamonte, P.; Krempel Merighe, G.; Watanabe, Y.F.; Caetano, A.R.; Vieira Meirelles, F. Development and optimization of a fluorescent differential display PCR system for studying bovine embryo development in vitro. Gen. Mol. Res. 2005, 4, 726-733.

21. Keiji, K.; Takashi, I.; Yoshiyuki, S. Fluorescent differential display analysis of expression in differentiating neuroblastoma cells. Gene 1997, 184, 73-81.

22. Dong-Kug, C.; Takashi, I.; Yuko, M.; Yoshiyuki, S. Fluorescent differential display analysis of expression inapoptotic neuroblastoma cells. Gene 1997, 223, 21-31.

23. Gevers, D.; Danielsen, M.; Huys, G.; Swings, J. Molecular characterization of tet(M) genes in Lactobacillus isolates from different types of fermented dry sausage. Appl. Environ. Microbiol. 2003, 69, 1270-1275.

24. Champomier-Verges, M.C.; Marceau, A.; Mera, T.; Zagorec, M. The pepR gene of Lactobacillus sakei is positively regulated by anaerobiosis at the transcriptional level. Appl. Environ. Microbiol. 2002, 68, 3873-3877.

25. Axelsson, L.; Lindstad, G.; Naterstad, K. Development of an inducible gene expression system for Lactobacillus sakei. Lett. Appl. Microbiol. 2003, 37, 115-120.

26. Bonomo, M.G.; Ricciardi, A.; Zotta, T.; Parente, E.; Salzano, G. Molecular and technological characterization of lactic acid bacteria from traditional fermented sausages of Basilicata region (Southern Italy). Meat Sci. 2008, 80, 1238-1248.

(C) 2009 by the authors; licensee Molecular Diversity Preservation International, Basel, Switzerland. This article is an open-access article distributed under the terms and conditions of the Creative Commons Attribution license (http://creativecommons.org/licenses/by/3.0/). 